\title{
Peran Dewan Komisaris, Komite Audit, Struktur Kepemilikan Perusahaan dan Perataan Laba Perusahaan Manufaktur
}

Kartini Soeharto ${ }^{1}$

${ }^{1}$ Universitas Soedirman, Jl. Srengseng Sawah, Jagakarsa, Jakarta Selatan, 12640

\section{INFO ARTIKEL}

JEL Classsification:

M40

G30

Keywords:

Income Smoothing,

Effectiveness

of the Board of

Commissioners, Audit

Committee, Ownership

\section{ABSTRACT}

This study aims to examine and analyze empirically the influence of the role of the board of commissioners, and audit committee, corporate ownership structure on income smoothing practices using the Eckel index, the influence of the role of the board of commissioners and audit committee is measured using the checklist score based on the characteristics of independence, activity, number of members and competence. The ownership structure is measured by the percentage of ownership. Control variables are entered into the model to neutralize the influence of unnecessary external variables. The sample is 135 manufacturing firm years listed in the Indonesia Stock Exchange. Hypothesis testing is done by logistic regression test. The test results show that the audit committee has a higher probability of practicing income smoothing, while the board of commissioners and ownership structure do not affect the income smoothing practice.

\begin{abstract}
ABSTRAK
Penelitian ini bertujuan untuk menguji dan menganalisis secara empiris pengaruh peran dewan komisaris, dan komite audit, struktur kepemilikan perusahaan terhadap praktik perataan laba dengan menggunakan indeks Eckel, pengaruh peran dewan komisaris dan komite audit diukur mengunakan score checklist berdasarkan karakteristik independensi, aktivitas, jumlah anggota dan kompetensi, sedangkan struktur kepemilikan diukur dengan persentasi jumlah kepemilikannya dengan menggunakan variabel kontrol untuk menetralisir pengaruh variabel-variabel luar yang tidak perlu. Sampel adalah 135 data tahun perusahaan manufaktur yang terdaftar di Bursa Efek Indonesia. Pengujian dilakukan dengan uji regresi logistik. Hasil pengujian menunjukkan bahwa komite audit memiliki probabilitas lebih tinggi untuk melakukan praktik perataan laba, sedangkan dewan komisaris dan struktur kepemilikan tidak berpengaruh terhadap praktik perataan laba.
\end{abstract}

\section{Pendahuluan}

Perkembangan dalam dunia bisnis pada saat sekarang ini menunjukkan adanya gejala persaingan yang makin meningkat. Adanya gejala tersebut menyebabkan manajemen perusahaan selalu ingin menunjukkan kinerja terbaik dalam setiap kegiatan yang dilakukannya. Salah satu instrumen perusahaan yang digunakan untuk menampilkan kinerjanya kepada pihak internal maupun eksternal adalah informasi laba yang dituangkan dalam bentuk laporan keuangan,

*Email Korespondensi: ${ }^{1}$ kartinisoeharto@yahoo.com 
dan salah satu pola manajemen laba yang umum digunakan perusahaan untuk tujuan tertentu adalah perataan laba (income smoothing), hal ini dilakukan manajemen agar laporan keuangan perusahaan tidak mencerminkan keadaan yang sebenarnya tentang hal-hal yang terjadi di perusahaan yang seharusnya diketahui oleh pemakai laporan keuangan perusahaan.

Fenomena yang terjadi pada tahun 2001 di Indonesia terjadi pada salah satu perusahaan manufaktur, yaitu PT Kimia Farma Tbk. Kementerian BUMN dan BAPEPAM menilai bahwa laba bersih yang telah dilaporkan sebesar 132 milyar tersebut terlalu besar dan mengandung unsur rekayasa. Kesalahan pada laporan yang telah disajikan PT Kimia Farma Tbk berkaitan dengan persediaan, karena nilai yang terdapat dalam daftar harga persediaan yang digelembungkan. Contoh skandal lain adalah dugaan terjadinya insider trading atas saham PT. Bank Central Asia tahun 2001, kasus Lippo Bank, kasus Telkom. Adanya kegagalan beberapa perusahaan dan timbulnya kasus malpraktik keuangan tersebut sebagai akibat dari buruknya praktik corporate governance.

Pada penelitian yang dilakukan oleh Prabayanti dan Yasa (2009), dengan judul "Perataan Laba (Income Smoothing) dan Analisis Faktor-faktor yang Mempengaruhinya (Studi Pada Perusahaan Manufaktur yang Terdaftar di BEI)", dengan menggunakan variabel profitabilitas, financial leverage, kepemilikan institusional dan reputasi auditor dan alat analisis binary logistic regression mendapatkan hasil bahwa ukuran perusahaan, kepemilikan institusional, reputasi auditor tidak berpengaruh signifikan terhadap perataan laba, sedangkan profitabilitas dan financial leverage berpengaruh negatif pada perataan laba.

Pada penelitian yang dilakukan oleh Aji dan Mita (2010), dengan judul "Pengaruh profitabilitas, risiko keuangan, nilai perusahaan, dan struktur kepemilikan terhadap praktik perataan laba: Studi empiris perusahaan manufaktur yang terdaftar di BEI", dengan variabel profitabilitas, risiko keuangan, nilai perusahaan, dan struktur kepemilikan mendapatkan hasil bahwa profitabilitas dan struktur kepemilikan tidak berpengaruh signifikan terhadap praktik perataan laba, nilai perusahaan dan risiko keuangan berpengaruh signifikan terhadap praktik perataan laba.

Pada penelitian yang dilakukan oleh Dewi (2011) dengan judul "Analisa faktor-faktor yang mempengaruhi praktik perataan laba (income smoothing) pada perusahaan manufaktur dan keuangan yang terdaftar di BEI (20062009)", dengan variabel ukuran perusahaan, profitabilitas, financial leverage dan dengan menggunakan alat analisis regresi logistik binomial, menghasilkan ukuran perusahaan berpengaruh signifikan terhadap tindakan perataan laba, profitabilitas, financial leverage dan jenis industri tidak berpengaruh signifikan terhadap tindakan perataan laba.

Pada penelitian yang di lakukan oleh Budiasih (2006), dengan judul "Faktorfaktor yang mempengaruhi praktik perataan laba", dengan variabel ukuran perusahaan, profitabilitas, financial leverage, dividend payout ratio dan dengan alat analisis regresi linier berganda, menghasilkan bahwa ukuran perusahaan, profitabilitas, dan dividend payout ratio berpengaruh signifikan terhadap praktik perataan laba, financial leverage tidak berpengaruh signifikan terhadap praktik perataan laba.

\section{Telaah Teori dan Pengembangan Hipotesis}

Menurut Fathi dan Esfahani (2012) teori keagenan merupakan basis teori yang mendasari praktik bisnis perusahaan selama ini. Teori tersebut berakar dari sinergi teori ekonomi, teori keputusan, sosiologi, dan teori organisasi. Prinsip utama teori ini menyatakan adanya hubungan kerja antara pihak yang memberi wewenang yaitu investor dengan pihak yang menerima wewenang (agensi) yaitu manajer. Pemisahan pemilik dan manajemen di dalam 
literatur akuntansi disebut dengan Agency Theory (teori keagenan). Teori ini merupakan salah satu teori yang muncul dalam perkembangan riset akuntansi yang merupakan modifikasi dari perkembangan model akuntansi keuangan dengan menambahkan aspek prilaku manusia dalam model ekonomi.

Salah satu faktor yang memicu praktik income smoothing adalah adanya rasio leverage yang besar. Sehingga menyebabkan minat investor untuk menanamkan modalnya pada perusahaan menurun dan akhirnya memicu praktik income smoothing yang dilakukan oleh agent. Agent juga memiliki kesempatan menggunakan dana perusahaan dengan memanfaatkan arus kas bebas untuk melakukan investasi atau keuangan lain yang dapat mempengaruhi tingkat keuntungan perusahaan secara keseluruhan, sehingga meningkatkan pula pendapatan pribadinya.

\section{Hubungan Dewan Komisaris dan Perataan Laba}

Berdasarkan teori mengenai dewan komisaris dan penelitian-penelitian sebelumnya, karakteristik dari dewan dapat mempengaruhi kualitas laporan keuangan baik diukur dengan tingkat manajemen laba maupun tingkat kandungan informasi laba. Penelitian Fauziah dan Marissan (2014) menunjukkan bahwa dewan komisaris mempunyai peran monitoring dalam menurunkan atau menghambat manajemen laba. Penelitian Dhaliwal et al. (2007) karakteristik dewan yang berpengaruh pada efektivitas peran dewan adalah jumlah dari dewan, independensi dari dewan, kepemilikan saham oleh dewan dan CEO-Chair duality (CEO sekaligus menjadi ketua dari board).

Dewan komisaris bertugas mengawasi kebijakan direksi dalam menjalankan perusahaan dan memberikan nasehatnya. Komisatis bersifat independen, tidak terlibat dalam pengelolaan perusahaan dan diharapkan mampu melaksanakan tugasnya secara objektif, semata-mata untuk kepentingan perusahaan, terlepas dari pengaruh berbagai pihak lainnya. Efektivitas pelaksanaan tugas dewan komisaris terbukti dipengaruhi oleh beberapa karakteristik, yaitu independensi, aktivitas, size dan kompetensi dewan komisaris (Petra, 2007); Dhaliwal, 2007; Xieet al., 2003; Jao dan Pagalung (2011); (Hermawan, 2009). Dengan demikian kemungkinan manajemen laba yang dilakukan dapat dipengaruhi oleh karakteristik dewan komisaris.

Karakteristik dewan komisaris tersebut merupakan satu kesatuan yang tidak terpisahkan dalam mempengaruhi efektivitas peran dewan komisaris. Hermawan (2009) menyatakan skor tersebut mencerminkan tingkat efektivitas dari dewan komisaris dalam menjalankan tugasnya. Apabila perusahaan memiliki skor efektivitas dewan komisaris yang tinggi berarti peran pengawasan dewan komisaris diharapkan efektif untuk mencegah dilakukannya praktik perataan laba. Maka hipotesis penelitian yang pertama adalah:

H1: Dewan Komisaris berpengaruh signifikan terhadap Perataan Laba.

\section{Hubungan Komite Audit dengan Perataan Laba}

Komite audit memerlukan kualifikasi khusus yang memadai untuk menjalankan tugas dan tanggung jawabnya, kualifikasi atau karakteristik dari komite audit ini diharapkan dapat menjadi suatu dasar kepercayaan terhadap para anggota komite audit untuk nantinya dapat bekerja maksimal dan sebaik mungkin. Penelitian Dhaliwal et al (2007) menyatakan tiga karakteristik yang menentukan kuatnya governance dari komite audit, yaitu jumlah anggota komite audit, independensi komite audit dan frekuensi rapat komite audit. Herman (2006) menggunakan empat karakteristik, yaitu independensi, aktivitas, jumlah anggota dan kompetensi dari komite audit. Mehrazeen et al (2012) hasil penelitiannya bahwa komite audit memiliki pengaruh terhadap perataan laba, berbeda dengan Yang et al. (2007) dan Gusnadi 
dan Budiharta (2008) menyatakan bahwa komite audit tidak berpengaruh terhadap praktik perataan laba.

Komite audit merupakan organ dari dewan komisaris yang bertugas membantu dewan komisaris dalam pengawasan penyusunan laporan keuangan perusahaan. Oleh sebab itu, apabila peran komite audit benar-benar efektif, perusahaan seharusnya akan mencegah terjadinya praktik perataan laba yang tidak terkontrol. Efektivitas peran komite audit dipengaruhi oleh beberapa karakteristik seperti yaitu independensi, aktivitas, jumlah anggota, kompetensi komite audit yang telah dibuktikan oleh peneliti-peneliti sebelumnya, (Xie et al., 2003; Zhou dan Chen, 2004; Dhaliwal et al., 2007). Pengaruh karakteristik tersebut merupakan satu kesatuan dan diukur dalam skor. Apabila perusahaan memiliki skor efektivitas peran komite audit yang tinggi berarti komite audit melakukan pengawasan atas proses pelaporan keuangan perusahaan dengan efektif, sehingga dapat mencegah adanya praktik perataan laba, sehingga hipotesa penelitian kedua ini adalah:

H2: Komite Audit berpengaruh signifikan terhadap Perataan Laba.

\section{Kepemilikan Perusahaan Asing dan Perataan Laba}

Leuz et al. (2010) menyatakan bahwa perusahaan asing berhubungan negatif dengan manajemen laba. Di mana negara dengan aturan pengungkapan yang rendah dan perlindungan atas investor yang lemah akan menyebabkan investasi asing rendah akibat tingginya manajemen laba. Sehingga disimpulkan bahwa kepemilikan asing akan menyebabkan rendahnya praktik perataan laba. Yusuf dan Soraya (2004) di Indonesia menemukan bahwa perusahaan non asing lebih banyak melakukan praktik perataan laba dibanding dengan perusahaan asing. Torres et al. (2010) penelitiannya di Brazil menemukan bahwa pemodal asing tidak berpengaruh signifikan terhadap praktik perataan laba.
Perusahaan dengan kepemilikan asing akan cenderung melakukan pengungkapan yang lebih luas dibandingkan dengan perusahaan dengan kepemilikan domestik karena cenderung memiliki teknologi yang cukup, sehingga mendukung terciptanya sistem informasi manajemen yang lebih efisien, memberikan pelatihan yang cukup bagi tenaganya mengenai pekerjaan yang diberikan, kemungkinan juga terdapat permintaan informasi yang lebih besar kepada perusahaan dengan kepemilikan asing dari pelanggan, pemasok dan analisa masyarakat. Yusuf dan Soraya (2004) di Indonesia menemukan bahwa perusahaan non asing lebih banyak melakukan praktik perataan laba dibandingkan dengan perusahaan asing. Torres et al. (2010) penelitiannya di Brazil menemukan bahwa pemodal asing tidak berpengaruh signifikan terhadap praktik perataan laba. Hipotesis penelitian yang ke tiga ini adalah:

H3: Kepemilikan berpengaruh signifikan terhadap Perataan Laba.

\section{Ukuran (Size) Perusahaan dan Perataan Laba}

Budiasih (2009) juga menyatakan bahwa ukuran perusahaan berpengaruh positif terhadap perataan laba dimana semakin besar perusahaan maka semakin besar pula indikasi adanya praktik perataan laba. Karena perusahaan yang besar memiliki political cost yang lebih tinggi sehingga perusahaan besar cenderung melakukan perataan laba untuk menghindari pajak yang terlalu tinggi pada saat perusahaan memperoleh laba tinggi, dan mejaga citra perusahaan pada saat laba yang dihasilkan terlalu rendah.

Juniarti dan Corolina (2004) ukuran yang diproksikan dengan total asset tidak berpengaruh terhadap perataan laba karena perusahaan yang besar tidak selamanya diidentikkan dengan padat modal tetapi bisa jadi padat karya. Ukuran perusahaan adalah suatu skala dimana dapat diklasifikasikan besar kecil perusahaan menurut berbagai cara, antara lain total asset, log size, nilai pasar dan lain-lain. 


\section{Leverage dan Perataan Laba}

Financial leverage diproksikan dengan debt to total asset yang diperoleh melalui total utang dibagi dengan total asset. Menurut Sartono (2001) financial leverage menunjukkan proporsi penggunaan utang untuk membiayai investasinya. Semakin besar hutang perusahaan maka semakin besar pula risiko yang dihadapi investor sehingga investor akan meminta tingkat keuntungan yang semakin tinggi. Akibat kondisi tersebut perusahaan cenderung untuk melakukan praktik perataan laba. Zuhroh (1996) dan Jin dan Mas'ud (1998) hasil penelitiannya menunjukkan leverage dan harga saham menjadi pendorong terjadinya praktik perataan laba.

\section{Profitabilitas dan Perataan Laba}

Variabel profitabilitas ini sangat diperhatikan oleh investor karena berkaitan dengan kemampuan perusahaan dalam menghasilkan keuntungan. Profitabilitas diproksikan dengan return on asset (ROA). ROA diperoleh dari rasio laba bersih setelah pajak dengan total asset. Jatiningrum (2000) dan Ashari et al. (1994) menyatakan bahwa profitabilitas merupakan faktor pendorong cenderung melakukan income minimization saat memperoleh tingkat profitabilitas tinggi. Ashari et al (1994) menyatakan bahwa perusahaan yang tingkat return on asset rendah mempunyai kecenderungan yang lebih besar untuk melakukan praktik perataan laba, fluktuasi laba akan memberi dampak pada makin rendah atau menurunnya profitabilitas akan mendorong manajer untuk melakukan praktik perataan laba. Penelitian Aji dan Mita (2010) menyatakan bahwa return on asset tidak berpengaruh terhadap perataan laba karena semakin tinggi ROA maka perusahaan tersebut akan menjadi sorotan publik, sehingga perusahaan kemungkinan berusaha untuk tidak melakukan praktik perataan laba karena akan membahayakan kredibilitas perusahaan.

Variabel Independen

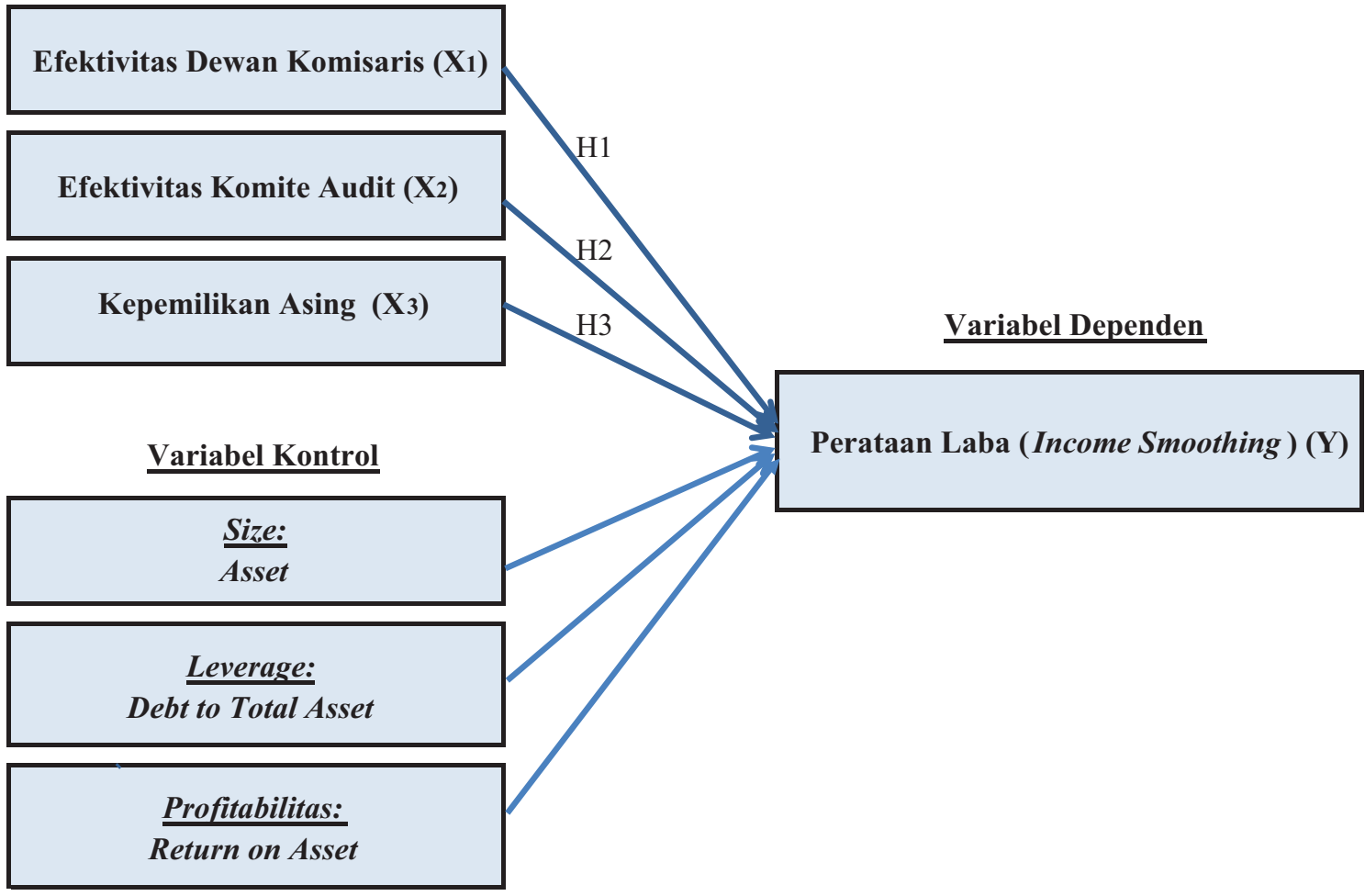

Gambar 1: Rerangka Pemikiran Teoritis

Pengaruh Peran Dewan Komisaris, Komite Audit, Struktur Kepemilikan Perusahaan Terhadap Perataan Laba 


\section{Metode Penelitian}

Populasi dalam penelitian ini difokuskan pada semua perusahaan manufaktur yang terdaftar di Bursa Efek Indonesia (BEI) selama periode penelitian yaitu dari tahun 2010 sampai dengan tahun 2014 yang terdiri dari 151 perusahaan manufaktur yang listing di BEI. Teknik penarikan sampel sampel dalam penelitian ini dipilih dengan menggunakan purposive sampling method yaitu teknik penentuan sampel dengan menetapkan beberapa pertimbangan dan kriteria dengan tujuan untuk mendapatkan sampel yang representative sesuai dengan kriteria yang ditentukan dan sesuai dengan tujuan penelitian. Proses pemilihan sampel dijabarkan pada tabel berikut ini:

Tabel 1: Deskripsi Sampel Penelitian

\begin{tabular}{lc}
\hline \multicolumn{1}{c}{ Keterangan } & Jumlah \\
\hline Perusahaan yang listing di Bursa Efek Indonesia 2010-2014 & 151 \\
Perusahaan yang delisting di Bursa Efek Indonesia pada periode 2010- & $(42)$ \\
2014 & $(52)$ \\
Perusahaan yang mengalami rugi pada periode 2010-2014 & $(6)$ \\
Perusahaan yang menggunakan satuan dollar & $(20)$ \\
Perusahaan dengan kategori data tidak lengkap/belum menerbitkan & $\mathbf{3 1}$ \\
Laporan Keuangan Tahunan sampai dengan 31 December 2014 & $\mathbf{1 5 5}$ \\
Sampel Akhir & $(20)$ \\
Jotal Sampel selama 5 (lima) tahun & $\mathbf{1 3 5}$ \\
Total akhir sampel
\end{tabular}

Sumber data: Data BEI, diolah

Pengumpulan data sekunder dilaksanakan dengan melakukan studi literature atau studi kepustakaan dengan cara mempelajari, meneliti, mengkaji serta menelaah buku, jurnal, literature dan informasi yang berhubungan dengan permasalahan yang di teliti, dengan tujuan untuk mendapatkan landasan teoritis dalam melakukan analisis dan sekaligus merupakan pedoman dalam studi dan penelitian di lapangan. Data yang diperlukan yaitu net income, net sales, return on asset, net profit margin, dan debt to total asset. Metode penelitian ini dipilih dengan menggunakan purposive sampling method dengan kriteria yang digunakan untuk memilih sampel.

Variabel dependen dalam penelitian ini adalah perataan laba (income smoothing). Untuk menentukan status perataan laba digunakan indeks Suwito dan Herawaty (2012). Kriteria perusahaan melakukan atau tidak melakukan perataan laba adalah sebagai berikut:

a. Perusahaan dianggap melakukan praktik perataan laba apabila indeks perataan laba lebih kecil daripada $1(\mathrm{CV} \Delta \mathrm{S}>\mathrm{CV} \Delta \mathrm{I})$.

b. Perusahaan dianggap tidak melakukan praktik perataan laba apabila indeks perataan laba lebih besar sama dengan daripada $1(\mathrm{CV} \Delta \mathrm{S}>\mathrm{CV} \Delta \mathrm{I})$.

Karena terdapat perusahaan yang melakukan perataan laba dan perusahaan yang tidak melakukan perataan laba, maka dalam pengujian ini variabel dependen menggunakan variabel dummy $(1,0)$ dan menggunakan binary logistic regression. Penetapan nilai 1 apabila perusahaan melakukan praktik perataan laba dan 0 apabila perusahaan tidak melakukan praktik perataan laba berdasarkan penelitian sebelumnya Gusnadi dan Budiharta (2008). 
Berikut ini income smoothing ratio menurut Suwito dan Herawaty (2012):

$$
\text { IS ratio }=\frac{\mathrm{CV} \Delta \text { net income }}{\mathrm{CV} \Delta \text { net sales }}
$$

Dimana:

IS ratio

$=$ Rasio perataan laba (income smoothing ratio)

$\mathrm{CV} \Delta$ net income $=$ Koefisien variasi untuk perubahan laba.

$\mathrm{CV} \Delta$ net sales $\quad=$ Koefisien variasi untuk perubahan penjualan.

CV

$=$ Coefficient of variation (standard deviation/ expected value) yaitu standar deviasi dibagi dengan nilai yang diharapkan.

Untuk menghitung CV (Coefficient of variation) untuk $\Delta$ net income dan $\Delta$ sales adalah sebagai berikut:

CV $\Delta$ net income dan CV $\Delta$ sales $=\sqrt{\frac{\Sigma(\Delta X-\Delta X)^{2}}{n-1}}: \Delta \bar{X}$

Keterangan:

$\Delta \mathrm{X} \quad$ : Perubahan net income atau sales antara tahun $\mathrm{n}$ dengan $\mathrm{n}-1$

$\Delta \mathrm{X} \quad$ : Rata-rata perubahan net income atau sales antara tahun $\mathrm{n}$ dengan $\mathrm{n}-1$

$\mathrm{n} \quad$ : Tahun yang di teliti

Variabel independen pada penelitian ini terdiri dari skor efektivitas dewan komisaris, skor efektivitas komite audit, perusahaan yang dikendalikan dan kepemilikan asing. Berikut akan dijelaskan mengenai variabel utama penelitian dan variabel kontrol yang digunakan dalam penelitian ini. Identifikasi variabel independen (independent), variabel terikat (dependent). variabel kontrol serta difinisi operasional secara terinci dapat disajikan dalam tabel sebagai berikut:

Tabel 2. Difinisi Operasional Variabel

\begin{tabular}{|c|c|c|c|c|}
\hline No & Variabel & Definisi Operasional & Skala & Pengukuran \\
\hline 1 & $\begin{array}{l}\mathrm{Y}= \\
\text { Perataan Laba } \\
\text { Indeks } \\
\text { Suwito dan } \\
\text { Herawaty } \\
(2012)\end{array}$ & $\begin{array}{l}\text { Usaha yang sengaja } \\
\text { dilakukan manajemen } \\
\text { untuk meratakan atau } \\
\text { memfluktuasi }\end{array}$ & Nominal & ISratio $=\frac{\text { CV } \Delta \text { net income }}{\mathrm{CV} \Delta \text { net sales }}$ \\
\hline 2 & $\begin{array}{l}\mathrm{X}_{1} \mathrm{X}_{1}= \\
\text { Efektivitas } \\
\text { Dewan } \\
\text { Komisaris }\end{array}$ & $\begin{array}{l}\text { Karakteristik } \\
\text { dewan komisaris, } \\
\text { yang mencakup: } \\
\text { independensi, aktivitas, } \\
\text { jumlah anggota (size) } \\
\text { serta kompetensi } \\
\text { (expertise) }\end{array}$ & $\begin{array}{l}\text { Dummy } \\
\text { Skor } \\
\text { Checklist } \\
\text { kuesioner } \\
\text { IICD }\end{array}$ & $\begin{array}{l}\text { Dummy dengan nilai: } \\
1=\text { Good } \\
0=\text { Poor }\end{array}$ \\
\hline 3 & $\begin{array}{l}\mathrm{X}_{2} \mathrm{X}_{2}= \\
\text { Efektivitas } \\
\text { Komite Audit }\end{array}$ & $\begin{array}{l}\text { Karakteristik komite } \\
\text { audit, yang mencakup: } \\
\text { aktivitas, jumlah } \\
\text { anggota (size), serta } \\
\text { kompetensi (expertise) }\end{array}$ & $\begin{array}{l}\text { Dummy } \\
\text { Skor } \\
\text { Checklist } \\
\text { kuesioner } \\
\text { IICD }\end{array}$ & $\begin{array}{l}\text { Dummy dengan nilai: } \\
1=\text { Good } \\
0=\text { Poor }\end{array}$ \\
\hline
\end{tabular}




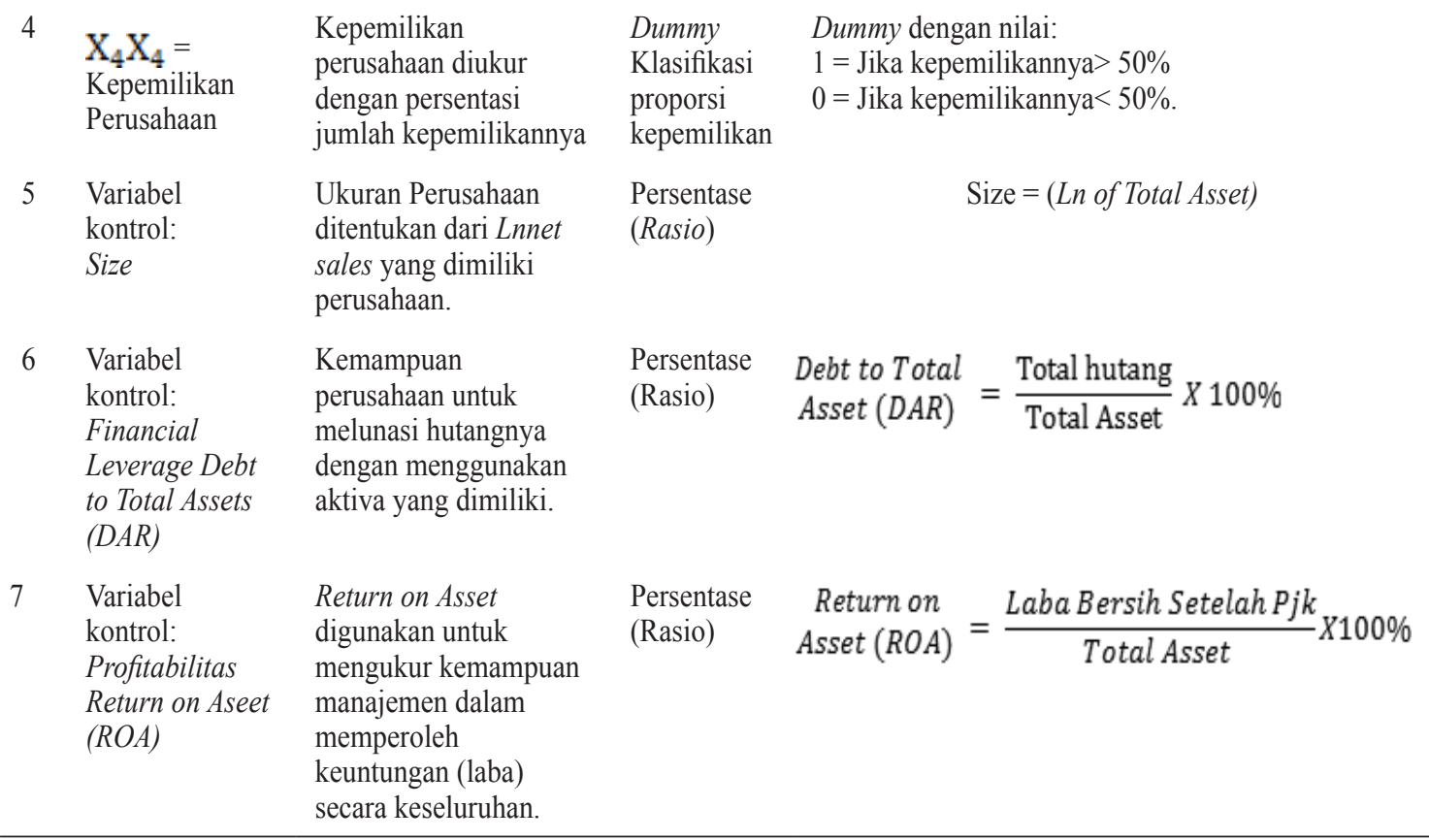

Sumber : Suwito (2012), Siregar dan Utama (2005), Gusnadi dan Budiharta (2008), Hermawan (2009), Yusuf dan Soraya (2010), (IICD).

Pengembangan model yang menghubungkan pengaruh efektivitas corporate governance, perusahaan yang dikendalikan kepemilikan asing terhadap perataan laba menggunakan regresi logistik. Regresi logistik adalah bagian dari analisis regresi yang digunakan ketika variabel dependen merupakan variabel dikotomi. Variabel dikotomi biasanya hanya terdiri dari atas dua nilai, yang mewakili kemunculan atau tidak adanya suatu kejadian yang biasanya diberi angka 0 dan 1. Menurut Gujarati (2003) regresi logistik adalah pendekatan dari pemodelan matematika yang digunakan untuk menjelaskan hubungan antara beberapa variabel independen dengan variabel dependen yang memiliki nilai dikotomus yaitu 0 dan 1 . Sedangkan menurut Pramono (2013) logistic regression sebetulnya mirip dengan analisis diskriminan yaitu menguji apakah probabilitas terjadinya variabel terikat dapat diprediksi dengan variabel bebasnya. Persamaan logistic regression dapat dinyatakan sebagai berikut, yaitu:

$$
\begin{gathered}
\mathrm{Ln} \frac{\mathrm{P}(\text { smoothing })}{1-\mathrm{P}(\text { smoothing })}=\text { IS }_{i t}=\beta+\beta_{1} \text { SCOREBD }_{i t}+\beta_{2} \text { SCOREAC }_{i t}+\beta_{4} \text { SCOREOWN }_{i t}+ \\
\beta_{5} \text { SIZE }_{i t}+\beta_{6} \text { LVRG }_{i t}+\beta_{7} \text { PROFIT }_{i t}+\varepsilon_{i t}
\end{gathered}
$$

Keterangan:

\section{Ln}

$\mathrm{P}$

IS
: $\quad \log$ of odds

: Probabilitas/kemungkinan tindakan income smoothing

: Perataan laba atau income smoothing menggunakan variabel dummy $(1,0)$, dimana 1 adalah perusahaan yang melakukan praktik perataan laba dan 0 adalah untuk perusahaan yang tidak melakukan praktik perataan laba.

$$
\text { ISratio }=\frac{\mathrm{CV} \Delta \text { net income }}{\mathrm{CV} \Delta \text { net sales }}
$$

Dimana:

ISratio $=$ Rasio perataan laba (income smoothing ratio) 


\section{$\mathrm{CV} \quad=$ Coefficient of variation}

$\mathrm{CV} \Delta$ net income dan CV $\Delta$ sales $=\sqrt{\frac{\Sigma(\Delta X-\Delta X)^{2}}{n-1}}: \Delta \bar{X}$

$\beta \quad$ : Koefisien regresi logit

SCOREBD $_{i t}$ : Skor dewan komisaris perusahaan i pada tahun $\mathrm{t}$

Diukur dengan menghitung skor efektivitas dari dewan komisaris (terdiri dari independensi, aktivitas, size dan kompetensi)

SCOREAC $_{i t} \quad$ : Skor komite audit perusahaan i pada tahun $\mathrm{t}$

Diukur dengan menghitung skor efektivitas dari dewan komite audit (terdiri dari aktivitas, size dan kompetensi)

FOREIGN $_{i t}$ : Perusahaan yang dimiliki oleh asing (foreign Ownership) perusahaan i pada tahun $\mathrm{t}$

Diukur dengan membagi jumlah lembar saham yang miliki oleh penanam modal asing dengan jumlah lembar saham yang beredar. Menggunakan variabel dummy, diberi nilai 1 jika proporsi kepemilikan modal asing $>50 \%$ dan 0 jika proporsi kepemilikan modal asing $<50 \%$.

$S I Z E_{i t} \quad: \quad$ Ukuran (size) perusahaan i pada tahun $\mathrm{t}$

Perusahaan diukur dengan total asset perusahaan

$\mathrm{LVRG}_{i t} \quad: \quad$ Leverage perusahaan i pada tahun $\mathrm{t}$

Diukur dengan debt to total asset yang diperoleh melalui total utang dibagi dengan total asset

PROFIT $_{i t} \quad$ : Profitabilitas diukur dengan return on asset (ROA) perusahaan i pada tahun $\mathrm{t}$ ROA diperoleh dari rasio laba bersih setelah pajak dengan total asset.

$\varepsilon_{\mathrm{it}} \quad: \quad$ Error term perusahaan i pada tahun $\mathrm{t}$

Pengujian statistik dilakukan dengan analisis multivariate dengan menggunakan regresi logistik (logistic regression), yang variabel bebasnya merupakan kombinasi antara metric dan non metric (nominal) dan tidak memerlukan uji normalitas dan uji asumsi klasik pada variabel bebasnya. Gujarati (2003) menyatakan bahwa regresi logistik mengabaikan heteroscedasticity, artinya variabel terkait tidak memerlukan homoscedasticity untuk masingmasing variabel bebasnya. Analisis statistik deskriptif digunakan untuk mendeskripsikan nilai minimum, maksimum mean dan nilai standard deviasi dari variabel-variabel yang ada dalam penelitian ini.

\section{Hasil dan Pembahasan}

Dari 155 perusahaan manufaktur selama periode 2010-2014 yang terbagi dalam 3 sektor yang di klasifikasikan oleh Bursa Efek Indonesia (BEI) dan dengan menggunakan indeks Suwito dan Herawaty (2012) terdapat 44 perusahaan manufaktur yang melakukan perataan laba, seperti terlihat pada tabel 3 distribusi sampel perusahaan manufaktur di bawah ini:

Tabel 3. Distribusi Sampel Perusahaan Manufaktur Tahun 2010-2014

\begin{tabular}{|c|c|c|c|c|c|c|c|c|}
\hline No & & $\begin{array}{l}\text { Sektor Kedua (Industri } \\
\text { Manufaktur) }\end{array}$ & $\begin{array}{c}\text { Income } \\
\text { Smoothing }\end{array}$ & $\begin{array}{c}\text { Non Income } \\
\text { Smoothing }\end{array}$ & Total & $\begin{array}{c}\% \\
\text { Income } \\
\text { Smoothing }\end{array}$ & $\begin{array}{c}\% \\
\text { Non Income } \\
\text { Smoothing }\end{array}$ & $\begin{array}{c}\% \\
\text { Total Sampel }\end{array}$ \\
\hline 1 & 3. & Basic Industry and Chemic: & 18.00 & 42.00 & 60.00 & $11.61 \%$ & $27.10 \%$ & $40.74 \%$ \\
\hline 2 & 4. & Miscellaneous Industry & 11.00 & 29.00 & 40.00 & $7.10 \%$ & $18.71 \%$ & $22.22 \%$ \\
\hline 3 & 5. & Consumer Goods Industry & 15.00 & 40.00 & 55.00 & $9.68 \%$ & $25.81 \%$ & $37.04 \%$ \\
\hline \multicolumn{3}{|c|}{ Jumlah Sampel } & 44.00 & 111.00 & 155.00 & $28.39 \%$ & $71.61 \%$ & $100.00 \%$ \\
\hline
\end{tabular}

Sumber: Data sekunder terpilih dan sudah di olah 
Income Smoothing dalam penelitian ini di ukur dengan menggunakan Regresi Binary Logistic, berdasarkan tabel 4 Descriptive Statistics di atas terlihat bahwa income smoothing atau perataan laba mempunyai nilai rata-rata 0,28 serta nilai standar deviasi sebesar 0,452 . Kondisi tersebut menunjukkan bahwa sebesar $28 \%$ dari total 155 observasi menunjukkan bahwa sebanyak $28 \%$ observasi penelitian termasuk kategori perusahaan yang melakukan praktik perataan laba dan $72 \%$ perusahaan yang tidak melakukan praktik perataan laba.

Hasil statistik deskriptif untuk variabel Dewan Komisaris (SCOREBD) dengan nilai skor minimum 0,17 nilai maksimum 0,67 dan rata-rata skor 0,3488. Untuk variabel Komite Audit (SCOREAC) menunjukkan nilai skor minimum 0,17 nilai maksimum 0,50 dan ratarata skor 0,3299. Untuk variabel Kepemilikan (SCOREOWN) menunjukkan nilai skor minimum 0 yang berarti bahwa kepemilikannya $<50 \%$, nilai maksimum 1 yang berarti bahwa kepemilikannya $>50 \%$ dan hasil skor ratarata sebesar 0,32 ini berarti bahwa dari seluruh sampel penelitian yang akan di uji sebanyak $32 \%$ atau sebanyak 50 perusahaan dengan kepemilikan $>50 \%$.

Variabel kontrol Ukuran Perusahaan (SIZE) (Ln Size Total Asset) dalam penelitian ini diukur dengan menggunakan logaritma normal dari total asset. Hasil analisis dengan statistik terhadap ukuran perusahaan (size) menunjukkan bahwa nilai terendah atau nilai asset minimum adalah sebesar 19,86, nilai asset maksimum 33,09 dan nilai rata-rata asset yang dimiliki adalah sebesar 28,2710 dengan standar deviasi sebesar 2,00494, untuk nilai standar deviasi yang lebih kecil dari nilai rata-rata (mean) menunjukkan bahwa ukuran perusahaan sampel, memiliki besaran yang hampir sama antar masing-masing sampel.

Untuk variabel Financial Leverage (LVRG/ DAR) memiliki nilai minimum 0,04 dan nilai maksimum 0,71 serta nilai rata-rata sebesar 0,16346 hal ini menunjukkan bahwa kemampuan perusahaan untuk melunasi hutangnya dengan menggunakan aktiva yang dimiliki nilai terendah yaitu sebesar $4 \%$ sedangkan nilai tertingginya sebesar $71 \%$. Dan rata-rata perusahaan mampu melunasi hutangnya adalah sebesar 0,3812 atau $38,12 \%$, standar deviasinya menunjukkan nilai 0,16346 nilainya lebih kecil dari rata-ratanya yang menunjukkan bahwa tingkat penyebaran datanya homogen.

Untuk variabel Profitabilitas (PROFIT/ ROA) dengan nilai minimum 0,00 dan nilai maksimum 0,67 serta nilai rata-rata sebesar 0,1274. Hal ini menunjukkan bahwa kemampuan perusahaan untuk menghasilkan laba bersih dengan menggunakan total assetnya memiliki nilai terendah 0,00 atau sedangkan nilai tertingginya 0,67 atau sebesar $67 \%$. Nilai rata-rata (mean) menunjukkan nilai 0.1274 yang bebarti bahwa rata-rata perusahaan mampu menghasilkan laba bersih sebesar 0.1274 atau $12,74 \%$. Standar deviasinya menunjukkan nilai 0,10607, nilainya lebih kecil dari rata-ratanya yang menunjukkan bahwa tingkat penyebaran datanya homogen.

Nilai Chi-square dari pengujian Hosmer and Lemeshow's Test sebesar 7.087 dengan signifikansi ( $\mathrm{p}$-value) sebesar 0.527. Dengan demikian probabilitasnya lebih besar dari tingkat $\alpha$ (alpha) sebesar 0,05, maka Ho tidak dapat ditolak (diterima), hal ini berarti model binary yang di susun layak diterima untuk dianalisis lebih lanjut, disebabkan tidak ada perbedaan nyata antara klasifikasi yang dipresiksi dengan klasifikasi yang diamati. Hal ini menunjukkan bahwa model regresi logistik bisa digunakan untuk analisis selanjutnya. Estimasi chi-square ditujukan untuk mengetahui pengaruh dari dewan komisaris, komite audit dan ukuran perusahaan dalam memprediksi perataan laba.

Sedangkan persamaan logistik dari tabel dibawah, yaitu: 
Tabel 4. Hasil Uji Regresi Logistik

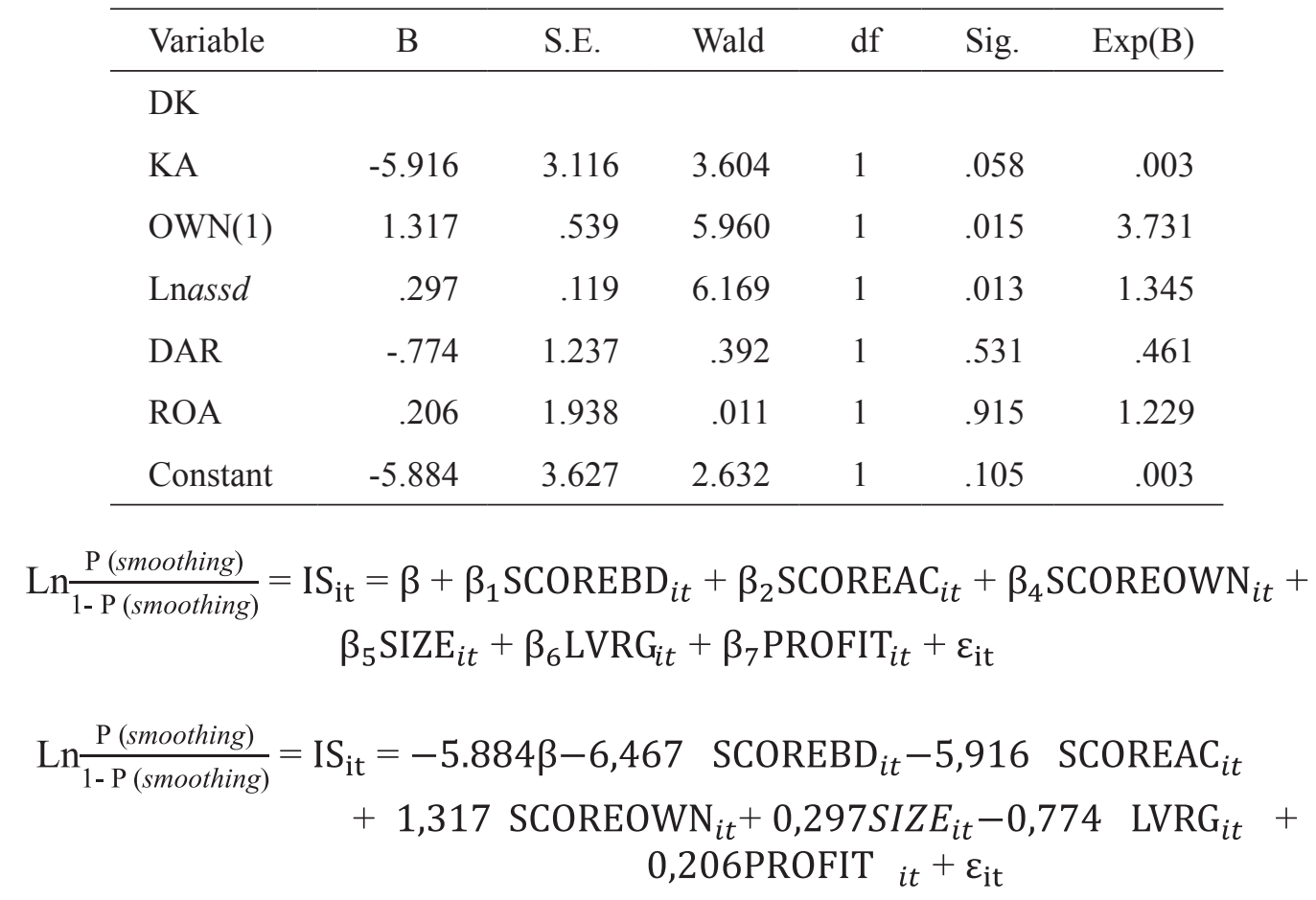

Dalam hal ini:

$\beta \quad$ : Konstanta regresi logistik

SCOREBD $_{i t}: \mathrm{X}_{1}$ - Skor dewan komisaris perusahaan i pada tahun $\mathrm{t}$

SCOREAC $_{i t}: \mathrm{X}_{2}$-Skor komite audit perusahaan i pada tahun $\mathrm{t}$

FOREIGN $_{i t}: \mathrm{X}_{3}$ - Kepemilikan perusahaan

SIZE $_{i t} \quad: \quad \mathrm{X}_{14}$ - Ukuran (size) perusahaan i pada tahun $\mathrm{t}$

LVRG $_{i t} \quad: \quad \mathrm{X}_{5}$ - Leverage perusahaan i pada tahun $\mathrm{t}$

PROFIT $_{i t}: \mathrm{X}_{6}$-Profitabilitas diukur dengan return on asset (ROA)

$\varepsilon_{i t} \quad: \quad$ Error term perusahaan i pada tahun $\mathrm{t}$

Overall Fit Model Test dilakukan dengan membandingkan nilai antara -2 Log Likelihood $(-2 L L)$ pada awal $($ Block Number $=0)$ dengan nilai -2 Log Likelihood (-2LL) pada akhir (Block Number =1). Statistik -2LL dapat digunakan untuk menentukan jika variabel bebas ditambahkan ke dalam model apakah secara signifikan memperbaiki model. Penurunan Likelihood (-2LL) ini menunjukkan model regresi yang lebih baik atau dengan kata lain model yang dihipotesiskan fit dengan data. Nilai -2LL awal adalah sebesar 184.937 setelah dimasukkan seluruh variabel independen, maka nilai -2LL akan mengalami penurunan menjadi sebesar 168.503. Hal ini menunjukkan bahwa terdapat penurunan -2LL sebesar 16.434 .
Penurunan Likelihood ini menunjukkan model regresi yang lebih baik atau dengan kata lain model yang dihipotesiskan fit dengan data, maka dapat disimpulkan bahwa model regresi ini layak digunakan.

Pengujian Omnimbus Test of Model Coeficient dapat dilihat dari chi-square (penurunan nilai -2 log likelihood) sebesar 16.434 dengan signifikansi sebesar 0.000 . Nilai signifikansi diketahui lebih kecil dari tingkat $\alpha$ (alpha), yaitu sebesar 0,05 menunjukkan bahwa model regresi binari logistik dapat menjelaskan adanya praktik perataan laba. Hasil pengujian Cox and Snell's $R$ Square (), Nagelkerke's $R$ Square dapat dilihat pada table 10. Nilai Nagelkerke's $R$ Square adalah sebesar 0.144 
yang berarti variabilitas perataan laba yang dijelaskan oleh variabel independen (efektivitas dewan komisaris, efektivitas komite audit, kepemilikan) adalah sebesar $14,40 \%$ sedangkan sisanya sebesar $85,60 \%$ dijelaskan oleh variabelvariabel lain diluar model penelitian.

Matriks Kualifikasi untuk prediksi perusahaan yang melakukan perataan laba adalah 44 perusahaan, sedangkan observasi sesungguhnya menunjukkan bahwa perusahaan yang melakukan perataan laba adalah sebanyak 8 perusahaan. Ketetapan model ini adalah $8 / 44$ atau $18,18 \%$ dan menurut prediksi perusahaan yang tidak melakukan perataan laba adalah sebesar 111 perusahaan, sedangkan observasi sesungguhnya menunjukkan bahwa perusahaan yang tidak melakukan perataan laba adalah sebanyak 107 perusahaan, maka ketetapan model ini adalah 107/111 atau 96,395\%. Adapun secara keseluruhan ketetapan model ini secara bersama sama untuk memprediksi ketetapan adanya perusahaan melakukan perataan laba dan tidak melakukan perataan laba sebesar 74,20.

\section{Pengaruh Dewan Komisaris Perusahaan Terhadap Praktik Perataan Laba}

Berdasarkan hasil hipotesis pengaruh dewan komisaris perusahaan terhadap praktik perataan laba menunjukkan bahwa dewan komisaris perusahaan yang diukur dengan score check list independensi kompetensi aktivitas dan size berpengaruh positif dan signifikan terhadap perataan laba. Hipotesis tersebut memberikan informasi bahwa variabel dewan komisaris memiliki nilai signifikansi sebesar 0,029<0,05. Hasil analisis penelitian ini dapat disimpulkan bahwa dewan komisaris tidak berpengaruh signifikan terhadap prediksi perataan laba, artinya peran dewan komisari perusahaan tidak melaksanakan fungsi dan tugasnya dalam melaksanakan good corporate governance.

Hasil analisis penelitian ini, konsisten dengan Mehrazeen et al. (2012), yang menunjukkan bahwa perusahaan yang memiliki dewan komisaris dalam jumlah banyak akan menyebabkan meningkatnya praktik perataan laba, kondisi tersebut dapat disebabkan karena sulitnya koordinasi antara anggota dewan, hal ini menghambat proses pengawasan yang harusnya menjadi tanggung jawab dari dewan komisaris.

Hasil penelitian ini sejalan dengan penelitian Gusnadi dan Budiharta (2008), Yang et al. (2007), Purwanto (2009) yang menguji dewan komisaris independen, ternyata tidak berpengaruh terhadap praktik perataan laba. Penelitian lain yang mendukung adalah Chalaki et al. (2012), bahwa board tidak berpengaruh terhadap kualitas pelaporan keuangan. Menurut Siregar dan Utama (2005) karena pengangkatan komisaris independen mungkin hanya dilakukan untuk pemenuhan regulasi saja tetapi tidak dimaksudkan untuk menegakkan Good Corporate Governance dan ketentuan minimun dewan komisaris independen sebesar $30 \%$ mungkin belum cukup tinggi untuk menyebabkan para komisaris independen tersebut mendominasi kebijakan perusahaan.

Pengujian empiris ini menyatakan bahwa dewan komisaris tidak berpengaruh terhadap perataan laba sesuai dengan hasil score check list yang telah dilakukan. Jika dilihat dari sisi independensi bahwa jumlah proporsi komisaris independen perusahaan sudah sesuai dengan peraturan Bursa Efek Indonesia, Bapepam dan LK, dimana setiap emiten harus memiliki jumlah komisaris independen sebesar minimal 30\% dari jumlah seluruh anggota komisaris.

Dari segi independensi juga menunjukkan bahwa sebagian besar emiten yang menjadi sampel ini tidak memiliki komite nominsi dan remunasi, seperti diketahui bahwa tujuan pembentukan komite nominasi dan remunerasi adalah untuk melaksanakan, mengatur dan menegakkan prinsip-prinsip tata kelola perusahaan yang baik sejalan dengan proses pencalonan posisi strategis dalam manajemen dan menetapkan besaran remunasi bagi direksi.

Dilihat dari sisi aktivitas dewan komisaris berdasarkan sampel yang diteliti menunjukkan 
bahwa dewan komisaris mengadakan rapat kurang dari empat kali dalam satu tahun, ini menunjukkan bahwa dewan komisaris merupakan badan yang bersifat paruh waktu yang hanya bertemu sesekali dan tidak saling kenal antara satu dengan yang lain. Sedangkan tingkat kehadiran rata-rata dewan komisaris selama setahun berjumlah kurang dari $70 \%$, ini berarti dewan komisaris kemungkinan tidak memiliki waktu dan keahlian yang diperlukan untuk memahami secara rinci bisnis perusahaan yang memungkinkan manajemen untuk mengaburkan masalah.

Hasil observasi check list untuk jumlah anggota dewan komisaris menunjukkan bahwa masih banyak perusahaan yang memiliki anggota dewan komisaris kurang dari lima, dan dilihat dari segi latar belakang pendidikan atau pekerjaan di bidang akuntansi atau keuangan untuk dewan komisaris masih sangat kurang. Artinya bahwa dewan komisaris tidak memiliki kemampuan memahami bisnis perusahaan sehingga dewan komisaris tidak bisa mencegah adanya praktik perataan laba.

\section{Pengaruh Komite Audit Perusahaan Terhadap Praktik Perataan Laba}

Berdasarkan tabel 6 di atas dengan regresi logistik menunjukkan bahwa pengujian hipotesa dua yang menguji pengaruh komite audit yang efektif terhadap probabilitas adanya praktik perataan laba dengan melihat hubungan antara nilai komite audit dengan probabilitas dari praktik perataan laba menunjukkan bahwa SCOREAC (komite audit) memiliki nilai positif dan signifikan sebesar $0,058<$ (alpha) $\alpha=10 \%$ berarti menunjukkan bahwa adanya komite audit yang efektif semakin menyebabkan adanya peningkatan praktik perataan laba.

Hasil penelitian ini konsisten dengan penelitian yang dilakukan oleh Fauziah dan Marissan (2014) dan Xie et al. (2003) menunjukkan bahwa komite audit mempunyai peran penting dan efektif dalam menurunkan atau menghambat manajemen laba. Mehrazeen et al. (2012) dalam penelitiannya terhadap komite audit memiliki pengaruh terhadap perataan laba.

Berdasarkan observasi penelitian dengan menggunakan skor efektivitas yang berupa daftar pertanyaan, ditemukan bahwa sekitar $73,29 \%$ perusahaan membuat laporan komite audit, akan masih banyak perusahaan yang tidak membuat laporan komite audit dan tidak melakukan evaluasi kinerja auditor eksternal, ini menunjukkan bahwa komite audit belum menjalankan fungsinya dengan benar, dan tidak berhasil menjalankan perannya sebagai salah satu elemen kunci dalam penerapan Good Corporate Governance (Siregar dan Utama, 2005).

Berdasarkan aktivitas komite audit perusahaan dalam penelitian ini rata-rata melaksanakan rapat komite audit kurang dari 4 kali dalam setahun, ini berarti menunjukkan ketidakjelasan fungsi dari komite audit dalam menjalankan tugas dari komite audit, sehingga diperkirakan komite audit tidak dapat mengendalikan adanya praktik perataan laba. Hasil penelitian ini sejalan dengan penelitian yang dilakukan oleh Bedard et al. (2004) dan Lin etal. (2009) yang menghasilkan kesimpulan penelitiannya bahwa tidak menemukan pengaruh yang signifikan rapat komite audit terhadap restatement laba.

\section{Pengaruh Kepemilikan Perusahaan Terhadap Praktik Perataan Laba}

Pengujian hipotesis pengaruh kepemilikan perusahaan terhadap praktik perataan laba menguji proporsiperusahaan dengan kepemilikan $\leq 50 \%$ dan kepemilikan $>50 \%$ dalam struktur permodalan perusahaan terhadap probabilitas terjadinya praktik perataan laba. Berdasarkan hasil regresi logistik yang ditunjukkan pada tabel 6 terlihat bahwa variabel SCOREOWN (kepemilikan) memiliki koefisien positif dan signifikan yaitu sebesar $0,015<$ dari 0,05 . Hasil pengujian tersebut menunjukkan bahwa proporsi kepemilikan saham tidak berpengaruh terhadap terjadinya praktik perataan laba atas laporan keuangan. 
Pengaruh Ukuran Perusahaan (size), Debt to Total Assets dan Return on Aset Terhadap Praktik Perataan Laba

Bardasarkan dari hasil analisis regresi binari logistik pada tabel 6 menunjukkan bahwa variabel kontrol dalam penelitian ini yaitu ukuran perusahaan tidak berpengaruh dan tidak signifikan terhadap adanya praktik perataan laba, sedangkan DAR dan ROA berpengaruh secara signifikan terhadap adanya praktik perataan laba.

Hasil analisis pada variabel ukuran (size) perusahaan menunjukkan koefisien yang positif, dan signifikan yang berarti bahwa semakin besar ukuran suatu perusahaan, maka semakin tinggi perusahaan melakukan praktik perataan laba. Variabel ukuran perusahaan ternyata tidak berpengaruh terhadap praktik perataan laba. Hasil penelitian ini sejalan dengan penelitian yang dilakukan oleh Gusnadi dan Budiharta (2008), Perwanto (2009) bahwa ukuran perusahaan tidak berpengaruh terhadap praktik perataan laba karena untuk negara berkembang seperti Indonesia, pemerintah akan mendorong perkembangan perusahaan untuk meningkatkan pertumbuhan ekonomi. Menurut Aji dan Mita (2010) perusahaan yang besar cenderung untuk tidak melakukan praktik perataan laba, selain itu transaksi pada perusahaan besar juga semakin kompleks sehingga praktik perataan laba semakin sulit untuk dilakukan.

Hasilpengujianuntukleveragemenunjukkan pengaruh positif, artinya bahwa semakin tinggi hutang maka perusahaan cenderung tidak melakukan praktik perataan laba. Hasil observasi menunjukkan bahwa variabel DAR tidak berpengaruh terhadap praktik perataan laba. Hal ini mungkin dikarenakan kebijakan utang yang ketat sehingga perusahaan sulit untuk memperoleh kredit sehingga manajer cenderung untuk tidak melakukan praktik perataan laba. Menurut hasil Zuhroh (1996), Jin dan Mas'ud (1998) hasil penelitiannya menunjukkan DAR dan harga saham menjadi pendorong terjadinya praktik perataan laba
$R O A$ ukuran penting dalam menilai sehat atau tidaknya perusahaan yang mempengaruhi investor untuk membuat keputusan berinvestasi. Pengujian terhadap variable $R O A$ menunjukkan pengaruh positif yang mengindikasikan bahwa ROA berpengaruh positif terhadap praktik perataan laba di tahun berjalan. Hal ini menandakan semakin tinggi tingkat ROA perusahaan maka perusahaan akan cenderung untuk tidak melakukan peratan laba karena perusahaan tersebut akan semakin menjadi sorotan publik, sehingga perusahaan kemungkinan berusaha untuk tidak melakukan tindakan yang membahayakan kredibilitas perusahaan.

Hasil penelitian menunjukkan bahwa variabel ROA tidak berpengaruh terhadap praktik perataan laba terbukti dengan nilai analisis sebesar $0,915>0,05$. Hasil penelitian ini sejalan dengan penelitian Aji dan Mita (2010) menyatakan bahwa ROA tidak berpengaruh terhadap perataan laba karena semakin tinggi ROA maka perusahaan tersebut akan menjadi sorotan publik, sehingga perusahaan kemungkinan berusaha untuk tidak melakukan praktik perataan laba karena akan membahayakan kredibilitas perusahaan yang bertentangan dengan Ashari et al (1994).

\section{Kesimpulan, Keterbatasan, dan Implikasi Hasil Penelitian}

Pengaruh dewan komisaris perusahaan terhadap praktik perataan laba menunjukkan bahwa dewan komisaris perusahaan berpengaruh positif dan signifikan terhadap perataan laba, dan disimpulkan bahwa dewan komisaris tidak berpengaruh signifikan terhadap prediksi perataan laba. Komite audit berpengaruh terhadap praktik perataan laba. Hal ini kemungkinan disebabkan pembentukan komite audit hanya berdasarkan kebutuhan, ada beberapa perusahaan yang tidak membuat laporan komite audit, tidak melaksanakan evaluasi kinerja auditor, ini menunjukkan komite audit belum 
menjalankan fungsinya dengan benar. Hasil pengujian hipotesis proporsi perusahaan dengan menunjukkan bahwa proporsi kepemilikan saham tidak berpengaruh terhadap probabilitas terjadinya praktik perataan laba atas laporan keuangan. Ukuran perusahaan sebagai variabel kontrol tidak berpengaruh dan tidak signifikan terhadap adanya praktik perataan laba, sedangkan DAR dan ROA berpengaruh secara signifikan terhadap adanya praktik perataan laba.

Penelitian ini memiliki beberapa keterbatasan, antara lain terdapat beberapa perusahaan yang laporan tahunannya tidak di sajikan secara detail. Metode yang digunakan dalam menghitung index perataan laba pada penelitian ini adalah menggunakan metode index eckel, jika terdapat metode lain yang bisa digunakan dalam mengukur perataan laba mungkin akan mendapatkan hasil yang lebih signifikan untuk bisa memenuhi penelitian selanjutnya. Penelitian selanjutnya diharapkan dapat lebih baik dari penelitian sebelumnya baik dari model penelitian, variabel, analisis, penambahan rentang waktu periode penelitian, populasi, sampel atau faktor lainnya yang terkait obyek penelitian sehingga hasilnya reliabel dan akurat. Saran untuk kepentingan praktisi implementasi bagi dunia usaha, manajemen, investor menerapkan mekanisme good corporate governance sesuai dengan prinsip yang berlaku. Bagi regulator badan usaha dan pasar modal harus lebih aktif dan berkolaborasi dengan kalangan dunia usaha, pelaku bisnis maupun investor, dalam hal menetapkan regulasi ataupun aturan, sosialisasi serta pengawasan praktek-praktek kalangan dunia usaha dalam hal penerapan Good Corporate Governance, harus sesuai dengan peraturan dan prinsip yang berlaku.

\section{Daftar Referensi}

Aji, Dhamar Yudho \& Mita, Aria Farah. (2010). Pengaruh Profitabilitas, Risiko Keuangan, Nilai Perusahaan, Dan Struktur Kepemilikan Terhadap Praktik Perataan Laba: Studi empiris Perusahaan Manufaktur Yang Terdaftar di BEI. Makalah SNA XIII. Purwokerto.

Ashari, N., Koh, H. C., Tan, S. L., \& Wong, W. H. (1994). Factors affecting income smoothing among listed companies in Singapore. Accounting and business research, 24(96), 291-301.

Budiasih, I. (2009). Faktor-faktor yang mempengaruhi praktik perataan laba. jurnal ilmiah akuntansi dan bisnis.

Budiharta, P. (2008). Analisis Pengaruh Karakteristik Perusahaan Dan Penerapan Good Corporate Governance Terhadap Tindakan Perataan Laba Yang Dilakukan Oleh Perusahaan Yang Terdaftar Di Bursa Efek Jakarta. Jurnal Ekonomi Dan Bisnis.

Chalaki, ParimDidar, Hamzeh\&Riahinezhad, M. (2012), Corporate Governance Attribute and Financial Reporting Quality: Empirical Evidence From Iran. International Journal of Business ans Social Science. Vol. 3. No. 15.

Dewi, R. K. (2011). Analisa Faktor-faktor yang Mempengaruhi Praktik Perataan Laba (Income Smoothing) pada Perusahaan Manufaktur dan Keuangan yang Terdaftar di BEI (2006-2009)(Doctoral dissertation, Universitas Diponegoro).

Corolina, C., \& Juniarti, J. (2006). Analisa faktor-faktor yang berpengaruh terhadap perataan laba (Income smoothing) pada perusahaan-perusahaan go public. Jurnal Akuntansi dan Keuangan, 7(2), 148-162.

Darwis, H. (2009). Corporate governance terhadap kinerja perusahaan. Jurnal Keuangan dan Perbankan, 13(3).

Dhaliwal, D. S., Naiker, V., \& Navissi, F. (2006). Audit committee financial expertise, 
corporate governance and accruals quality: An empirical analysis. Corporate Governance and Accruals Quality: An Empirical Analysis (May 2006).

Gujarati, D. N., \& Porter, D. C. (2003). Basic econometrics (4th, international ed.).

Hermawan, A. A. (2009). Pengaruh efektifitas dewan komisaris dan komite audit, kepemilikan oleh keluarga dan peran monitoring bank terhadap kandungan informasi laba. Disertasi S3 Program Ilmu Akuntansi. Universitas Indonesia.

Jatiningrum, A. (2000). Analisis Faktor-Faktor yang Berpengaruh terhadap Perataan Penghasilan Bersih/Laba pada Perusahaan yang Terdaftar di Indonesia. Jurnal Bisnis dan Akuntansi, 3(2), 145-155.

Jin, Liauw She dan Mas'udMachfoedz. (1998). "Faktor-faktor yang Mempengaruhi Praktik Perataan Laba Pada Perusahaan yang Terdaftar di Bursa Efek Jakarta”. Jurnal Riset Akuntansi Indonesia. Vol. 1(2).

Leuz, C., Nanda, D., \& Wysocki, P. D. (2003). Earnings management and investor protection: an international comparison. Journal of financial economics, 69(3), 505-527.

Lin, J. W., Li, J. F., \& Yang, J. S. (2006). The effect of audit committee performance on earnings quality. Managerial Auditing Journal, 21(9), 921-933.

Mehrazeen, Aki Reza \&Mehrtash, Mazuyeh. (2012). Corporate Governance and Income Smoothing in Iran. Journal of Basic and Applied Scientific Research. 2 (4). 31883194.

Petra, S. T. (2007). The effects of corporate governance on the informativeness of earnings. Economics of Governance, 8(2), 129-152.

Prabayanti, N. L. P. A., \&Yasa, G. W. (2010). Perataan Laba (Income Smoothing) Dan Analisis Faktor-Faktor Yang Mempengaruhinya (Studi Pada Perusahaan Manufaktur Yang Terdaftar Di Bursa. Jurnal
Ilmiah Akuntansi dan Bisnis.

Sartono, Agus. (2001). Manajemen Keuangan, Teori dan Aplikasi. Edisi Keempat. Yogyakarta : BPFE.

Torres, D., Bruni, A. L., Martinez, A. L., \& Rivera, M. A. (2010). Ownership and Control Structure, Corporate Governance and Income Smoothing in Brazil.

Xie, B., Davidson III, W. N., \& DaDalt, P. J. (2003). Earnings management and corporate governance: the role of the board and the audit committee. Journal of corporate finance, 9(3), 295-316.

Yang, C. Y., Leing Tan, B., \& Ding, X. (2012). Corporate governance and income smoothing in China. Journal of Financial Reporting and Accounting, 10(2), 120-139.

Yusuf, M., \& Soraya, S. (2004). Faktor-Faktor yang Mempengaruhi Praktik Perataan Laba pada Perusahaan Asing dan Non Asing di Indonesia. Indonesian Journal of Accounting and Auditing, 8(1).

Zhou, J., \& Chen, K. Y. (2004). Audit committee, board characteristics and earnings management by commercial banks. Unpublished Manuscript.

Zuhroh, D. (1996). Faktor-faktor yang Berpengaruh pada Tindakan Perataan Laba pada Perusahaan go public di Indonesia (Doctoral dissertation, Universitas Gadjah Mada).

Fauziah, F. E., \&Marissan, I. (2014). Pengaruh corporate social responsibility (CSR) terhadap kualitas laba dengan corporate governance sebagai variabel moderating. Jurnal Akuntansi dan Auditing, 11(1), 39-61.

Jao, R., \&Pagalung, G. (2011). Corporate governance, ukuran perusahaan, dan leverage terhadap manajemen laba perusahaan manufaktur Indonesia. Jurnal akuntansi dan auditing, 8(1), 43-54.

Suwito, E., \&Herawaty, A. (2012). Analisis pengaruh karakteristik perusahaan terhadap tindakan perataan laba yang dilakukan oleh 
perusahaan yang terdaftar di Bursa Efek Jakarta.

Pramono, O. (2013). Analisis pengaruh ROA, NPM, DER, dan Size terhadap praktik perataan laba (studi kasus pada perusahaan Manufaktur yang terdaftar di Bursa Efek Indonesia periode 20072011). Calyptra, 2(2), 1-16.

Purwanto, A. (2009). Karakteristik Perusahaan, Praktik Corporate Governance, Keputusan Keuangan, Perataan Laba Dan Nilai Perusahaan. MAKSI, 9.

Fathi, S., Zarei, F., \&Esfahani, S. S. (2012). Studying the role of financial risk management on return on equity. International Journal of Business and Management, 7(9), 215. 